Article

\title{
Agricultural Land Conversion, Land Economic Value, and Sustainable Agriculture: A Case Study in East Java, Indonesia
}

\author{
Mohammad Rondhi ${ }^{1, *}$ (]) Pravitasari Anjar Pratiwi ${ }^{1}$, Vivi Trisna Handini ${ }^{1}$, \\ Aryo Fajar Sunartomo ${ }^{2}$ and Subhan Arif Budiman ${ }^{3}$ \\ 1 Department of Agribusiness, University of Jember, Jember 68121, Indonesia; \\ pravita.anjar@unej.ac.id (P.A.P.); vivi.trisna@unej.ac.id (V.T.H.) \\ 2 Department of Agricultural Extension, University of Jember, Jember 68121, Indonesia; \\ aryo.faperta@unej.ac.id \\ 3 Department of Soil Science, University of Jember, Jember 68121, Indonesia; sabudiman@unej.ac.id \\ * Correspondence: rondhi.faperta@unej.ac.id; Tel.: +62-81291495040
}

Received: 12 October 2018; Accepted: 28 November 2018; Published: 30 November 2018

check for updates

\begin{abstract}
Agricultural land conversion (ALC) is an incentive-driven process. In this paper, we further investigate the inter-relationship between land economic value (LEV) and ALC. To achieve this goal, we calculated the LEV for agricultural and non-agricultural (housing) uses in two areas of East Java, Indonesia. The first area represents peri-urban agriculture, which is facing rapid urbanization and experiencing a high rate of ALC. The second area represents rural agriculture, with zero ALC. Furthermore, we identified factors affecting LEV in both areas for both uses. The results of this study show that agricultural land yielded a higher economic benefit in rural areas. Conversely, compared to agricultural land, housing in urban areas yields a value that is seven times higher. Moreover, agricultural land was shown to yield a higher profit after conversion. Ironically, a similar comparison does not exist in rural areas. Agricultural land yielded a value that was only 19\% higher, indicating that agricultural land can easily be converted. This is also proven by the growing number of new urban cores in the periphery area. There are several factors affecting land economic value, such as agricultural use, soil fertility, accessibility, and cropping pattern, which are important variables. Meanwhile, the accessibility and location of peri-urban areas increase the land value for housing.
\end{abstract}

Keywords: agricultural land conversion; land economic value; urbanization; land rent; sustainable agriculture

\section{Introduction}

Land is one of the most important aspects of life. In agricultural production, the role of land, as the main input, is irreplaceable. Economically, land is the most efficient wealth-generating asset for farmers [1,2] and is also an important factor for economic growth [3]. However, the limited and unrenewable nature of land supply creates a fierce land-use competition, usually between the agricultural and non-agricultural sectors. This gives rise to agricultural land conversion (ALC), which significantly reduces the agricultural land availability and threatens food supply. Ironically, the highest rate of ALC occurs in developing countries [4], which are characterized by a massive population and high food consumption [5]. Thus, the proper management of ALC is important for stabilizing the food supply. In addition to ALC, another important problem relating to agricultural land (AL) is the degradation of land quality caused by unsuitable cropping patterns [6]. In an effort to maximize economic gains, farmers tend to overexploit land by cultivating a high-value crop, which is 
basically unsuitable for the land characteristics $[7,8]$. This produces a high economic return for the farmer, although in the longer term, the land quality will be degraded, thus sacrificing future food production for short-term economic gains.

Of all the causes of ALC, urbanization caused the most rapid and irreversible change [9]. It promoted the formation of the peri-urban area in the agricultural region, close to the urban core $[10,11]$. The peri-urban area is defined as an area where the process of peri-urbanization, characterized by a changing economic and employment structure, rapid urbanization, and population growth, rising land costs, but with a large amount of land still in agricultural use, is underway [11]. Many studies have stated the importance of agriculture in peri-urban areas. Peri-urban agriculture can improve the condition of the environment by mitigating the urban heat effect and reducing flood risk [12,13], creating green outdoor spaces for the urban population [14-16] and a source of income, especially for the poor $[17,18]$. Moreover, in the development context, the important role of peri-urban agriculture has often been stated. McGee [19] argued that the peri-urban area is a crucial zone for supporting food security, with its resource base and proximity to the urban core. Peri-urban agriculture also played an important role for urban sustainability [20], providing income opportunities, delivering food and fiber, and reversing the trend of environmental degradation in the urban area [21]. Thus, it is important to keep land in the peri-urban area as agricultural land.

Based on traditional location theory, the conversion of agricultural land is caused by the relatively higher rent that is created from urban land use, compared to agricultural land use [22-24]. ALC in developing countries is rapid and mostly unplanned. As most urban area is surrounded by productive agricultural land [25], uncontrolled ALC directly diminishes food production and the provision of ecosystem goods and services derived from these land types [26]. Thus, it is important to control ALC. To achieve this goal, it is crucial to look at the root cause of ALC in the first place. As previously mentioned, the major cause of ALC is the differing rent that is created from urban and agricultural land use. The higher rent of urban land use will promote further ALC. Conversely, the increasing rent of agricultural land will limit ALC. Actually, land rent for urban and agricultural uses are affected by many factors. Hence, ALC can be controlled by focusing on important factors that increase agricultural rent and that decrease nonagricultural (urban) rent. Diagrammatically, this argument is provided in Figure 1.

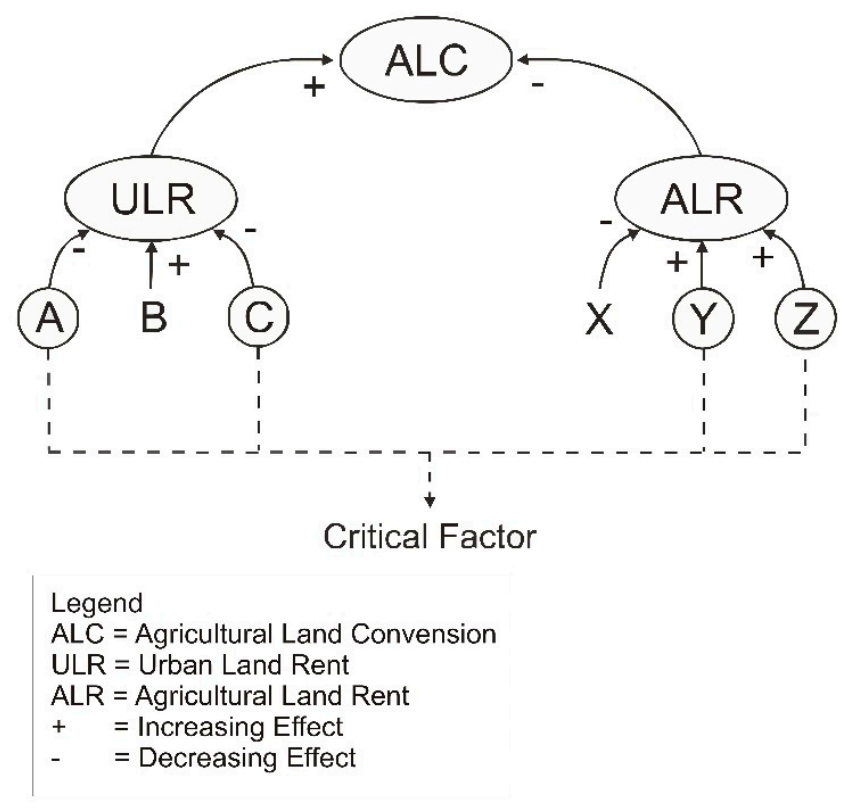

Figure 1. Relation between land rent and agricultural land conversion. 
Previous studies on land economic value have shown that it significantly affects the decision of farmers to sell or not to sell their land for non-agricultural purposes. In Europe, the Common Agricultural Policy (CAP), through decoupled payments and environment schemes, increases land value, because farmers convert CAP payment into land value [27-30]. Those payments increase farmland value and make farmers unwilling to sell it for non-agricultural use. Furthermore, the increase in farmland value promotes a land use conflict, both between farmers (for agricultural use) and between farmers and non-farmers (for non-agricultural uses) [31]. Moreover, the increase in land economic value due to urbanization in Bangladesh makes real estate and individual developers speculate and develop buildings in restricted areas, including productive agricultural land [32]. In Indonesia, rapid urbanization increases the demand for housing, resulting in a high demand for land for housing development, thus increasing the value of agricultural land for non-agricultural use. The increasing land economic value for housing is translated into massive ALC, and creates an area called a peri-urban area [33]. These studies show that land economic value is the main driver of ALC. However, few studies stress the policy implication of this finding. Furthermore, studies focusing on the impact of urbanization on agricultural land in Indonesia were conducted only in large metropolitan cities [34-38], and little research was conducted on medium- and small-sized cities, where the process of urbanization has just begun.

The general purpose of conducting this study is to examine the relative value of agricultural and non-agricultural land in areas with a high rate of ALC (peri-urban) and areas with zero ALC (rural). The specific purpose of this paper is to measure land rents for agricultural and housing uses in peri-urban and rural areas, in the district of Jember of the Province of East Java. Furthermore, this paper identifies factors affecting land rents for both uses in both areas.

\section{Materials and Methods}

\subsection{Agricultural Land Conversion in Indonesia}

The rate of ALC in Indonesia is 187,720 ha/year, and most of the converted land was used for housing and industrial site development [39]. Housing development accounted for $48.96 \%$ of converted land, followed by industrial (36.50\%) and offices building development (14.55\%) [40]. The major causes of ALC in Indonesia is the high demand for land for non-agricultural use, and the low return to traditional agricultural production [39]. The rapid urban development in peri-urban areas increases the value of ALC for urban use and thus gives farmers a higher incentive to convert their land. Moreover, farmers often perceive selling their land as an opportunity to find a more promising jobs, and as an effective way to earn quick cash and invest in other sectors [39].

In 2009, the Indonesian government issued a statute to protect and control the rate of ALC, under UU No. 41 Tahun 2009. There are two major mechanisms proposed to control ALC. First, prohibiting the conversion of agricultural land by forming "Sustainable Agricultural Land" (LP2B, standing for Lahan Pertanian Pangan Berkelanjutan). LP2B is farmland that is protected by law and cannot be converted for other uses for a period of 20 years. The determination of LP2B is conducted by the local government (District Level) by issuing regional law (PERDA) regarding the area intended to become LP2B, and secondly, by giving incentives to farmers to maintain their agricultural activity. Specifically, the form of incentives involve decreasing land tax, improving agricultural infrastructure, funding research and development into high yield varieties, ease of access to agricultural information and technology, providing farm input, securing land tenure, and rewarding the achievements of farmers [41]. The main intention of this mechanism is to increase the economic value of agricultural activity, since increasing the economic value of agriculture will lessen the likelihood that farmers will convert their land for other use. 


\subsection{Study Area}

This study was conducted in two different villages in Jember District (Kabupaten), which is located in the Province of East Java (Figure 2). Jember is one of the main agricultural regions in Java. It has a total of 3293.34 square kilometers of land, and agriculture accounts for $50.1 \%$ of the total land use. In Indonesia, agricultural production is concentrated in the island of Java, and East Java is one of the main agricultural regions. In East Java, rice production is mainly concentrated in Jember. However, Jember's economy is experiencing a structural transformation, from an agricultural to an industrial and service-based economy. Consequently, the rate of ALC in Jember has increased in the past decade.
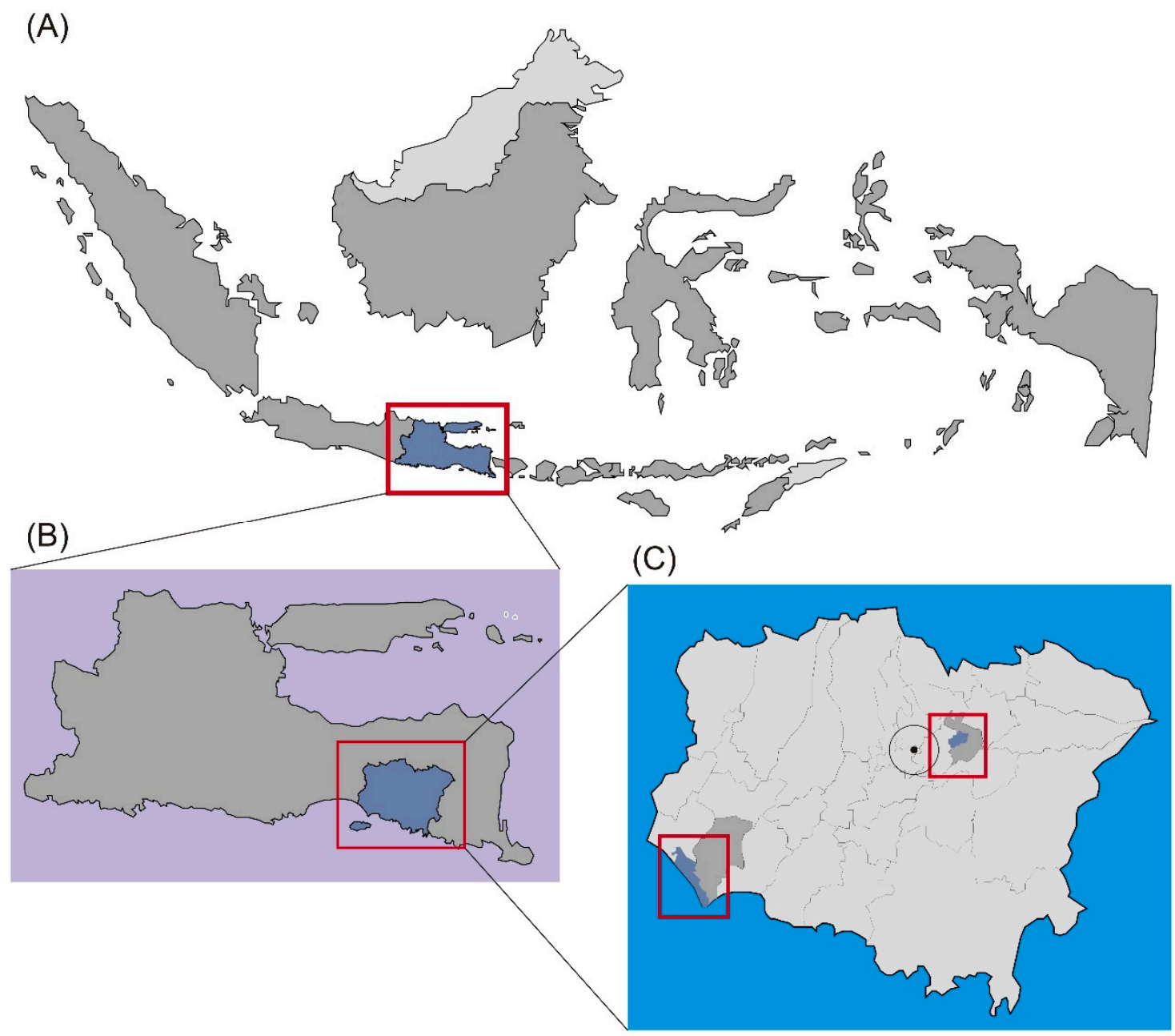

Figure 2. Map of the study area, (A) Province of East Java, relative to Indonesia, (B) Jember District relative to the Province of East Java, (C) Map of Jember District, the highlighted area show Gumukmas (lower) and Sumbersari (upper) Subdistricts. The circle indicates the urban core of the city of Jember.

Between 2009 and 2016, the annual rate of ALC in Jember was 71 hectares (0.085\%). Most of the converted land was used for housing and industrial development. Of 31 subdistricts, ALC occurred only in nine subdistricts, and the highest ALC was $8.6 \%$, and the lowest was $0.7 \%$ [42]. However, the pattern of ALC shows some important information. There are 22 subdistricts that do not experience ALC, however, the rate of agricultural land growth is zero. This means that ALC will continue to grow in the next few years. Moreover, Jember's municipality area consists of three subdistricts, in which the rate of ALC is high, and the fact that there are six other subdistricts that experienced ALC shows that there is a new urban core. Furthermore, this new urban core was previously an agricultural region. Thus, it is important to study the land economic value in the urban and rural regions. 
The first village was Kepanjen, located in Gumukmas Subdistrict (Kecamatan). Kepanjen is the representative of the agricultural economy. Kepanjen has experienced zero ALC during 2009-2016, and the main planted crops are horticulture and food crops (Figure 3). Kepanjen has an area of 14.78 square kilometers and a population of 10,515 inhabitants, resulting in a population density of 711 person/square kilometer.
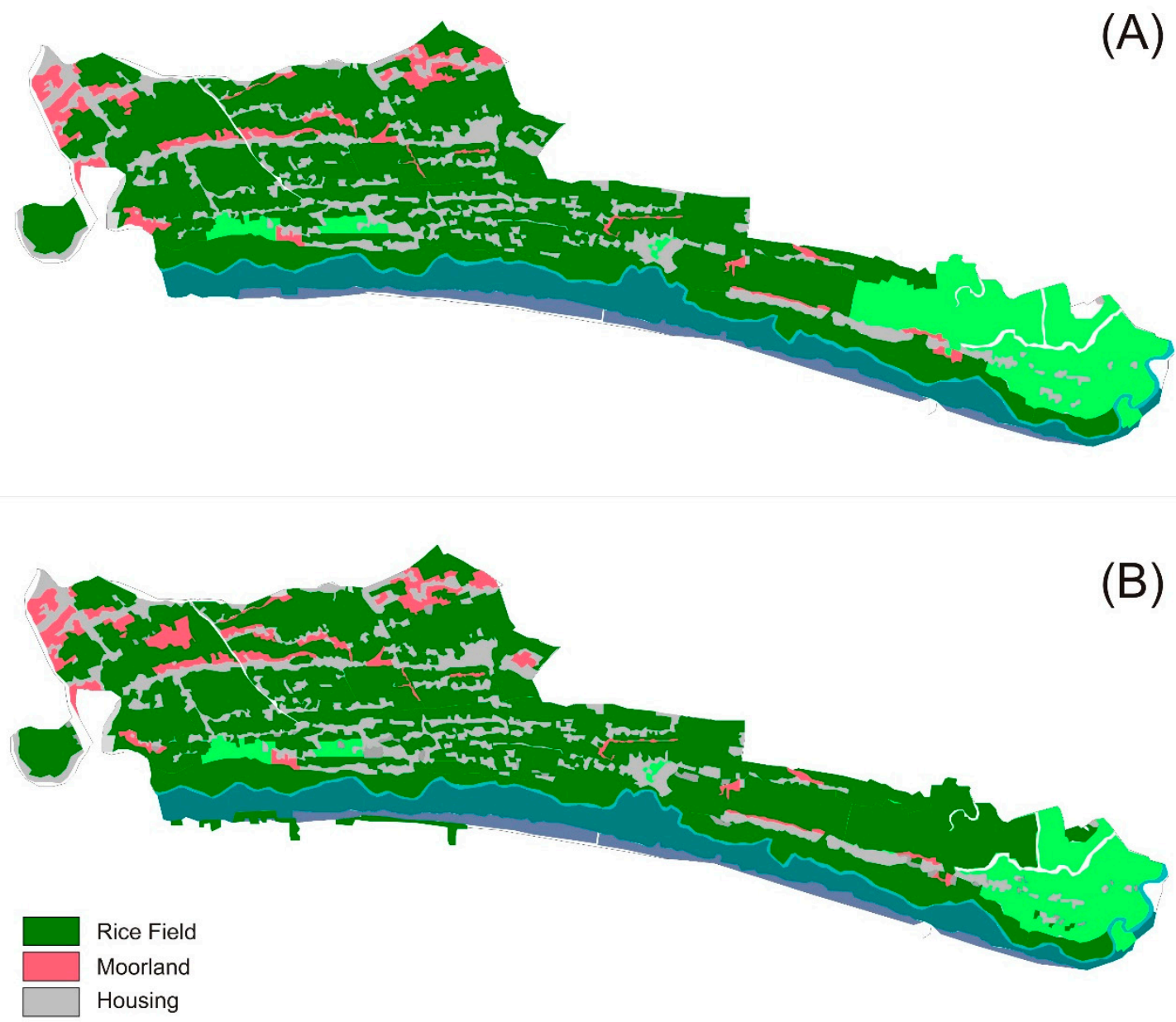

(B)

Figure 3. Map of Kepanjen Village. (A) Land use distribution in 2012. (B) Land use distribution in 2017, showing a relatively constant trend of agricultural land and housing.

The second village was Antirogo, which is located in Sumbersari Subdistrict. Antirogo is the representative of a peri-urban agricultural area. It is located $7 \mathrm{~km}$ from Jember downtown and experienced a rapid ALC of 8.6\% during 2009-2016 (Figure 4). The average rate of ALC in Jember during 2009-2016 was $0.085 \%$, which shows that ALC is concentrated in the suburban area. Antirogo has a population density of 1359 persons/square kilometer. The selection of these villages was based on practical reason, since both villages are in agriculturally based regions, and Kepanjen continues to remain in agriculture, while Antirogo demonstrates a significant shift in its economic structure to a more industrialized economy. Both farmers and home-owners in both villages were selected as respondents in this study.

The sampling procedure used was multi-stage random sampling. In the first stage, the population of farmers and home-owners in both villages were enumerated. In the first stage, we identified 6061 home-owners (3011 in Kepanjen and 3050 in Antirogo) and 1839 farmers (783 in Kepanjen and 1056 in Antirogo). In the second stage, we randomly selected 50 farmers and 50 home-owners in each village, resulting in a total of 200 respondents. 
(A)

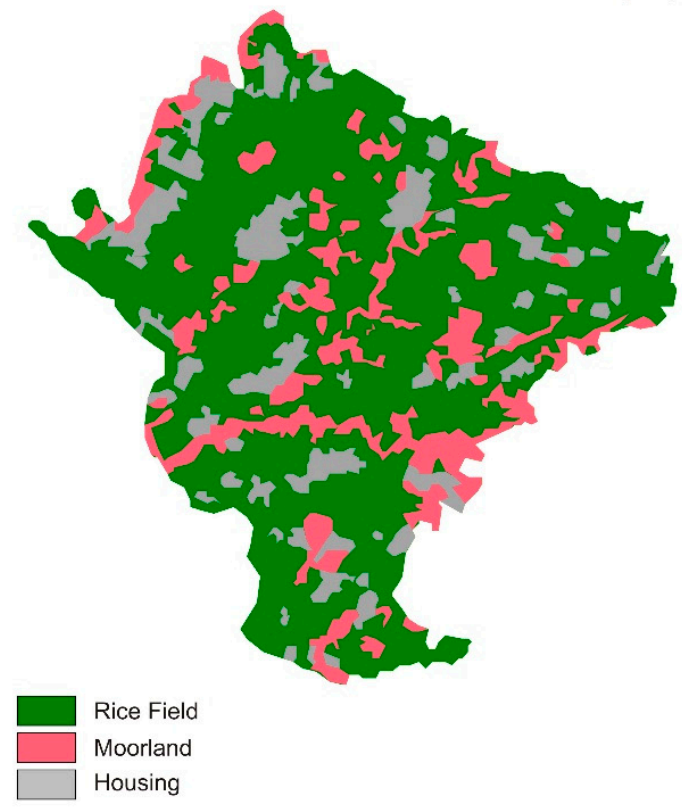

(B)

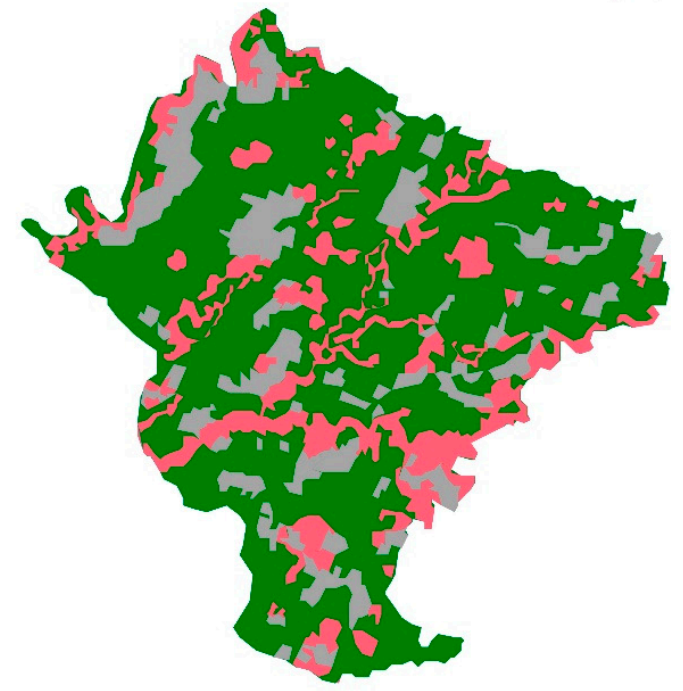

Figure 4. Map of Antirogo Village. (A) Land use distribution in 2012. (B) Land use distribution in 2017, showing a growing land area for housing.

\subsection{Data}

The data used in this study were collected from 100 farmers and 100 home-owners from each village. The farmers were selected based on the plot of land managed. Similarly, the home-owners were selected based on the house possessed. Thus, there were 200 distinct respondents in this study. The survey was performed between January and June 2018. The survey questionnaire had two parts. The first part focused on measuring land economic value, both for agricultural and housing uses, while the second part focused on eliciting farmer and home-owner characteristics.

We measured land economic value as the economic rent it produced for a period of one year. Economic rent for agricultural land is calculated as the profit obtained from farm production in a year. In the calculation of farm income, we calculated both the implicit and explicit cost, and deducted this from the gross revenue. The implicit cost is family labor. However, the use of family labor was found only in rural areas. Conversely, in peri-urban areas, hired labor was used in all of the stages of farming. Similarly, the economic rent of housing was calculated as the rental fee obtained by the home-owners from leasing their house for a period of one year, after deducting the house operational and maintenance costs. The rental value fee was estimated as the imputed rental fee (the amount of rental fee obtained, had the house been rented). There are eight variables that used to explain farmland characteristics, namely, land basic information (land area, land tenure, location), accessibility (distance to irrigation, distance to nearest market, and distance to road), cropping pattern, and soil fertility. The cropping pattern in both villages varied, and there are 10 patterns in Kepanjen, and two in Antirogo. The cropping pattern in Kepanjen is mostly food and horticultural crops, and food and seasonal plantation crops in Antirogo. All of these patterns were grouped into food crops (dummy value 0 ) and mixed crops (dummy value 1 ).

Soil fertility was determined by directly asking the farmers about their land. The use of self-reported soil fertility levels has been found to be useful, since farmers have a holistic view of their soil [43]. However, farmers defined soil fertility as a dynamic feature of the land. For the purpose of this paper, we defined fertile soil as soil with good productivity, since farmers often relate 
good soil with its ability to produce a higher yield. For this purpose, soil fertility was grouped into fertile land (1) and less fertile land (0).

The descriptions in the farmland data used in this study-full sample, rural, and peri-urban areas-are shown in Table 1. The average differs slightly, although rural farmers have a wider land possession than their counterpart. It is also shown that agricultural land has easier access to irrigation, with only $42 \mathrm{~m}$ on average, compared to land in peri-urban areas, which are located $2053 \mathrm{~m}$ away on average. Both the distance to the nearest market and to the road tend not to be significantly different, as many farmers, both in rural and peri-urban areas, tend to sell their harvest to collecting traders directly on their plot. Most of the land is owned by farmers, and 88 percent of farmers in both villages cultivate their own land. However, most of them cultivate only food crops all year long, and only 33 percent of farmers perform mixed cultivation. In relation to soil fertility, most farmers (82 percent) regarded their land as fertile.

Table 1. Descriptive statistics of farmland.

\begin{tabular}{|c|c|c|c|c|c|c|c|c|}
\hline Variable & Code & Unit & \multicolumn{4}{|c|}{ Full Sample } & $\begin{array}{c}\text { Kepanjen } \\
\text { Mean }\end{array}$ & $\begin{array}{c}\text { Antirogo } \\
\text { Mean }\end{array}$ \\
\hline Land area & L.area & $\mathrm{m}^{2}$ & 4005 & 2515 & 1000 & 10,000 & 4211 & 3800 \\
\hline Distance to nearest market & Market & M & 4250 & 1305 & 2000 & 8000 & 4080 & 4420 \\
\hline Distance to road & Road & $\mathrm{M}$ & 113 & 147 & 1 & 1000 & 123 & 104 \\
\hline Land tenure & Tenure & owner (1), other (0) & 0.88 & 0.32 & 0 & 1 & 1 & 0.76 \\
\hline Soil fertility & Fertility & fertile (1), less fertile $(0)$ & 0.82 & 0.38 & 0 & 1 & 0.88 & 0.76 \\
\hline Location & Location & Peri-urban (1), rural (0) & 0.5 & 0.5 & 0 & 1 & 0 & 1 \\
\hline Observation & & & 100 & & & & 50 & 50 \\
\hline
\end{tabular}

There are six variables used to describe the housing conditions in both villages. Information regarding housing land characteristics are summarized in Table 2.

Table 2. Descriptive statistics for housing characteristics.

\begin{tabular}{|c|c|c|c|c|c|c|c|c|}
\hline Variable & Code & Unit & \multicolumn{4}{|c|}{ Full Sample } & $\begin{array}{c}\text { Kepanjen } \\
\text { Mean }\end{array}$ & $\begin{array}{c}\text { Antirogo } \\
\text { Mean }\end{array}$ \\
\hline Building area & B.area & $\mathrm{m}^{2}$ & 71 & 26 & 27 & 198 & 74 & 68 \\
\hline Distance to road & Road & $\mathrm{m}$ & 117 & 170 & 1 & 1000 & 184 & 50 \\
\hline Distance to downtown & Downtown & $\mathrm{m}$ & 6135 & 1670 & 3500 & 10,000 & 6350 & 5920 \\
\hline Water availability & Water & sufficient(1), insufficient(0) & 0.95 & 0.26 & 0 & 1 & 1 & 0.94 \\
\hline Observation & & & 100 & & & & 50 & 50 \\
\hline
\end{tabular}

Both peri-urban and rural houses have three rooms on average, which is typical in Indonesia. A slight difference exists in water availability, and 100 percent of rural houses have sufficient water, while 4 percent of houses in peri-urban areas do not have access to sufficient water. This shows that peri-urban development not only results in agricultural land conversion, but also starts to degrade the water quality. Peri-urban areas have easier access, both to road and to the downtown area, since both of these infrastructures are the result of economic development. By downtown, we mean the subdistrict center (kecamatan) of each village. The subdistrict center plays an important role in village life as the smaller urban center. Most of the major spending of villagers occurred there. Thus, it plays an important economic role. 


\subsection{Econometric Model and Estimation Procedures}

As previously mentioned, we calculated land economic value as the rent created by that land when used for agricultural or housing purposes. The economic rent created from agricultural land is calculated by Equation (1):

$$
l_{a t}=\frac{\left[\left(q_{i t} \times p_{i t}\right)-c_{i t}\right]}{L_{a}}
$$

where $l_{a t}$ is the agricultural land rent for year $t, q_{i t}$ is the quantity harvested in season $i$ of year $t, p_{i t}$ is the price of the harvested crop in season $i$ of year $t, c_{i t}$ is the total farming cost in season $i$ of year $t$, while $L_{a}$ is the land area. The economic rent created from housing is calculated by Equation (2).

$$
l_{h t}=\frac{\left[R_{t}-c_{t}\right]}{L_{h}}
$$

where $l_{h t}$ is the economic rent from housing in year $t, R_{t}$ is the rental fee of the house in year $t, c_{t}$ is house operational and maintenance costs in year $t$, while $L_{h}$ is the house building area.

After calculating land economic value, we then determined the factors affecting it. We employed multiple linear regression. Two equations were estimated in this stage. The first equation determines the factors affecting land economic value, both in rural and peri-urban areas (Equation (3)):

$$
l_{a i}=\alpha_{0}+\sum_{n=1}^{n} \alpha_{n} x_{i n}+\sum_{m=1}^{m} \beta_{m} D_{i m}+u_{i}
$$

where $i=1 \ldots 100, l_{a i}$ is the agricultural land value, $x_{n}$ is the quantitative variables, $D_{m}$ is the qualitative variables, and $\alpha_{0}, \alpha_{n}, \alpha_{m}$ are the regression intercept, and the coefficients for quantitative and qualitative variables, respectively. The description of each variable and their summary statistics are shown in Table 1. The second equation was used to estimate the factors affecting land economic value for housing and are shown in Equation (4):

$$
l_{h i}=\alpha_{0}+\sum_{n=1}^{n} \alpha_{n} x_{i n}+\sum_{m=1}^{m} \beta_{m} D_{i m}+u_{i}
$$

where $i=1 \ldots 100, l_{h i}$ is the land economic value for housing, $x_{n}$ is the quantitative variables, $D_{m}$ is the qualitative variables, and $\alpha_{0}, \alpha_{n}, \alpha_{m}$ are the regression intercept, and the coefficients for quantitative and qualitative variables, respectively. The description of each variable and their summary statistics are shown in Table 2. The data used in this study have been tested for autocorrelation, heteroscedasticity, and multicollinearity. The estimation of these equation was based on ordinary least squares estimation, and the estimation processes was conducted with SPSS Software (version 25; SPSS Inc., Chicago, IL, USA).

\section{Results}

\subsection{Land Economic Value}

Land rent analysis revealed that the peri-urban area has a lower value for agriculture, but a higher value for housing (Table 3). The average agricultural land value in the peri-urban area is $\operatorname{Rp} 4447 / \mathrm{m}^{2} /$ year, ranging between $\mathrm{Rp}-416 / \mathrm{m}^{2} /$ year and $\mathrm{Rp} 10,975 / \mathrm{m}^{2} /$ year. Meanwhile, in the rural area, it averaged $\mathrm{Rp} 6047 / \mathrm{m}^{2}$ /year, ranging between $\mathrm{Rp} 1600 / \mathrm{m}^{2} /$ year and $\mathrm{Rp} 19,504 / \mathrm{m}^{2}$ /year. Conversely, the average housing land value in the peri-urban area is $\mathrm{Rp} 39,904 / \mathrm{m}^{2} /$ year, with a wide range between $\mathrm{Rp} 7917 / \mathrm{m}^{2} /$ year and $\mathrm{Rp} 142,188 / \mathrm{m}^{2} /$ year, and this is seven times higher on average, compared to the conditions in the rural area. In the rural area, the housing value was only $\mathrm{Rp} 5059 / \mathrm{m}^{2} /$ year on average, ranging between $\mathrm{Rp} 278 / \mathrm{m}^{2} /$ year and $\mathrm{Rp} 14,908 / \mathrm{m}^{2} /$ year. There is a negative value in peri-urban agriculture, meaning that there are farmers who choose to remain in 
farmland, even at the expense of farming profits. At the same time, peri-urban housing yielded a value that was seven times higher, but the converse did not apply in the rural district, where agricultural land yielded a value that was only $19 \%$ higher.

Table 3. Land economic value for agricultural and housing purposes in the study area.

\begin{tabular}{ccccccccc}
\hline \multirow{2}{*}{ Land Use } & \multirow{2}{*}{ Unit } & \multicolumn{3}{c}{ Rural Area } & \multicolumn{3}{c}{ Peri-Urban Area } & \multicolumn{2}{c}{ Full Sample } \\
\cline { 3 - 8 } & & Mean & Min. & Max. & Mean & Min. & Max. & Mean \\
\hline Agriculture & $\mathrm{Rp} / \mathrm{m}^{2} /$ year & 6047 & 1600 & 19,504 & 4447 & -416 & 10,975 & 4997 \\
Housing & $\mathrm{Rp} / \mathrm{m}^{2} /$ year & 5059 & 278 & 14,908 & 39,954 & 7917 & 142,188 & 22,312 \\
\hline
\end{tabular}

Most farmers cultivate food crops all year long, although we found various cropping patterns and each cropping pattern has a different economic value (Table 4). In the rural area, non-food crop patterns are mixed with horticultural crops, while in the peri-urban area, non-food crop patterns are only mixed with seasonal plantation crops, such as tobacco. The land value reveals that non-food cropping patterns yielded a higher value. However, only 26 percent of farmers in rural areas, and 40 percent in peri-urban areas, cultivated non-food crops. Both horticultural and seasonal plantation crops require high farming costs, and also have greater production and price risks. Thus, only wealthier farmers, who were able to bear the greater farming costs and risks, plant these crops.

On the other hand, the growing number of commercial farmers in rural areas who cultivate horticultural crops poses a potential problem. Motivated by high economic gains, they tend to overexploit land by cultivating horticultural crops, which are basically unsuitable to the land characteristics. Horticulture in Kepanjen (and generally in Jember) uses chemical pesticides intensively (especially fungicides and herbicides). The average application frequency of pesticides is three times a week. This is significantly higher than in food crop farming, which involves the application of chemical pesticides only once every one to two weeks. Consequently, the land under horticulture receives a large amount of pesticide residue. Moreover, the soil structure in Kepanjen is sandy, which means that the residues will become absorbed rapidly. In a broader context, the pesticide residues pollute the groundwater. Since horticulture in Kepanjen is practiced close to residential areas, the pesticide residues will also pollute water used for domestic consumption. Water melon, one of the main horticultural crops, is planted all year long (with 3-4 cropping seasons on average). This further increases the amount of pesticide residue received by the soil. Moreover, farmers in Kepanjen did not remove the crop residues from the field, which means that more pesticides can infiltrate the soil. These practices generate a high economic value, but they will degrade soil and water quality in the long term.

In rural areas, the houses are located only on land previously intended for housing purposes. Conversely, there are houses built in converted land, previously used for agricultural production. The result of the analysis reveals that agricultural land yielded a higher economic value after being converted (Table 5). On average, converted agricultural land yielded Rp. $7917 / \mathrm{m}^{2} /$ year, ranging between Rp. 7917/ $\mathrm{m}^{2} /$ year and Rp. $42,230 / \mathrm{m}^{2} /$ year. This is significantly higher than when it was retained as agricultural land. Thus, it is logical for farmers to convert their land, since it gives them greater financial benefits than if they remain in agriculture. 
Table 4. Land economic value of agricultural land under different cropping patterns.

\begin{tabular}{|c|c|c|c|c|c|c|}
\hline \multirow{2}{*}{ Location } & \multirow{2}{*}{ Cropping Pattern } & \multirow{2}{*}{$\begin{array}{l}\text { Number of } \\
\text { Farmers }\end{array}$} & \multicolumn{3}{|c|}{ Cropping Season $\left(\mathrm{Rp} / \mathrm{m}^{2}\right)$} & \multirow{2}{*}{$\begin{array}{l}\text { Yearly Average } \\
\left(\mathrm{Rp} / \mathrm{m}^{2}\right)\end{array}$} \\
\hline & & & 1st & 2nd & 3 rd & \\
\hline \multirow[t]{11}{*}{ Rural } & paddy, paddy, paddy & 7 & 2049 & 1825 & 1649 & 5477 \\
\hline & paddy, paddy, maize & 22 & 1786 & 1711 & 1442 & 4893 \\
\hline & paddy, maize, maize & 5 & 2428 & 2068 & 1912 & 6336 \\
\hline & no crop, paddy, paddy & 1 & 0 & 1521 & 1455 & 2907 \\
\hline & no crop, paddy, maize & 2 & 0 & 1585 & 566 & 2111 \\
\hline & paddy, maize, chili & 4 & 1434 & 1196 & 715 & 3303 \\
\hline & paddy, maize, bitter melon & 2 & 2164 & 1637 & 7273 & 10,988 \\
\hline & paddy, bitter melon, bitter melon & 2 & 3288 & 4438 & 4438 & 12,072 \\
\hline & no crop, paddy, chili & 3 & 0 & 2932 & 2704 & 5603 \\
\hline & paddy, chili, chili & 1 & 1024 & 332 & 332 & 1600 \\
\hline & paddy, bitter melon, chili & 1 & 2445 & 6723 & 10,399 & 19,503 \\
\hline \multirow[t]{2}{*}{ Peri-urban } & paddy, paddy, maize & 30 & 1421 & 1590 & 706 & 2738 \\
\hline & paddy, paddy, tobacco & 20 & 1106 & 1336 & 4694 & 6777 \\
\hline
\end{tabular}

Table 5. Land economic value for converted agricultural land.

\begin{tabular}{cccc}
\hline \multirow{2}{*}{ Land Origin } & \multicolumn{3}{c}{ Economic Value $\left(\mathrm{Rp} / \mathbf{m}^{2} /\right.$ Year) } \\
\cline { 2 - 4 } & Mean & Minimum & Maximum \\
\hline Converted agricultural land & 7917 & 7917 & 42,230 \\
Housing & 45,063 & 45,063 & 142,188 \\
\hline
\end{tabular}

\subsection{Factors Affecting Land Economic Value}

Ordinary least squares estimation revealed that many variables affect the economic value of land used for agricultural and nonagricultural purposes. The estimation results of Equations (3) and (4) are presented in Table 6 . The $F$ test for the overall fit of both models are shown in Table 4 . This tests the null hypothesis that all coefficients in the models are 0 . Since the $F$ test $p$ value for both models are $p<0.05$ and $p=0.000$, the null hypothesis that all variable coefficients are 0 is rejected. Thus, it can be concluded that the model is better at estimating the land economic value for both agricultural and housing uses. The explained variance of the dependent variable can be measured with the $\mathrm{R}^{2}$ value. The $\mathrm{R}^{2}$ value of the first model is 0.656 , indicating that $65.6 \%$ of agricultural land value variation can be explained by the model. The $\mathrm{R}^{2}$ value of the second model is 0.640 , indicating that $64 \%$ of housing land value variation can be explained by the model. This percentage is satisfactory, since the models did not violate the normality, multicollinearity, homoscedasticity, and linearity assumptions.

Table 6. Estimation results.

\begin{tabular}{cccc}
\hline \multicolumn{2}{c}{ Agricultural Land } & \multicolumn{2}{c}{ Housing } \\
\hline Variables & Coefficients & Variables & Coefficients \\
\hline Intercept & $8890.691^{* * *}$ & Intercept & $4858.626^{\mathrm{ns}}$ \\
L.area & $-0.151^{* *}$ & B.area & $-108.330^{\mathrm{ns}}$ \\
Irrigation & $-0.338^{* *}$ & Room & $3206.109^{* *}$ \\
Market & $-1.052^{* * *}$ & Road & $-0.166^{\mathrm{ns}}$ \\
Road & $-4.145^{* * *}$ & Downtown & $-8.975^{* * *}$ \\
Tenure & $186.858^{\mathrm{ns}}$ & Location & $83,696.221^{* * *}$ \\
Crop & $1950.186^{* * *}$ & & \\
Fertility & $987.133^{*}$ & & \\
Location & $-0.151^{*}$ & & \\
$\mathrm{R}^{2}$ & 0.656 & $\mathrm{R}^{2}$ & 0.640 \\
$F$ test & $21.648^{* * *}$ & $F$ test & $33.450^{* * *}$ \\
Observation & 100 & Observation & 100 \\
\hline Note: ${ }^{* * *} p<0.01^{* *} 0.01>p>0.05, * 0.05>p>0.1, \mathrm{~ns}=p>0.1$.
\end{tabular}


The first model shows that seven out of eight variables estimated have significant $p$ values. As expected, the land area has a negative coefficient. Thus, the larger the land, the lower its economic value. There are two reasons for the obtained result. First, farmers with more land tend to cultivate food crops, which has a lower economic value compared to non-food crops (horticulture or seasonal plantation crops). Second, farmers with more land tend to use a lower quality of inputs (whether labor or non-labor inputs), thus reducing productivity and decreasing the rent created. Accessibility variables provided the expected result that the further the farmland is from irrigation, the nearest market, and the road, the lower the land value. Much of the selling of harvested crops occurred on farmland, although the seller usually charges larger transportation costs. The cropping pattern significantly affected the land value, where non-food crops generated $\mathrm{Rp} 1950.186 / \mathrm{m}^{2} /$ year on average, which is a higher value compared to that of food crop patterns. Soil fertility was also reported to have increased the land economic value by $\mathrm{Rp} 987.133 / \mathrm{m}^{2} /$ year on average. Furthermore, as expected, farmland located in peri-urban areas generated a lower value, compared to that in rural areas. However, land tenure does not significantly affect land value. The explanation for this result is that all farmers from rural areas cultivated their own land, resulting in little variation in the data.

The second model shows that three out of five estimated variables have a significant effect on housing land value. The number of rooms and the accessibility to the downtown area were shown to significantly affect the land value. Most house renters in the studied area place a greater importance on the number of rooms than on the size of the building, since most of them rent the house in groups. ${ }^{1}$ Thus, the greater the number of rooms, the greater the economic value it generates. Furthermore, people prefer to live as close as possible to the downtown area, since most of their activity is conducted there. Furthermore, as expected, the value generated by houses located in peri-urban areas is $\mathrm{Rp}$ $83,696.221 / \mathrm{m}^{2} /$ year, higher than that of those located in rural areas.

\section{Discussion}

\subsection{Land Economic Value and Agricultural Land Conversion}

The main purpose of this study was to calculate land rent in rural and peri-urban areas. The point of conducting this study in these areas was to compare the land economic value in an area with zero ALC (rural) and an area with high ALC (peri-urban). Our result demonstrates that there is a significant difference in land economic value in these areas (Figure 5). In the rural area, land creates a higher value when used for agricultural purposes, while in the peri-urban area, it creates a higher value when used for housing purposes. However, although creating a higher value, agricultural production in rural areas has a value that is only $19 \%$ higher, compared to housing uses. This is significantly different to the condition in peri-urban areas, where housing has a $790 \%$ higher value. This significant difference indicates that there is a strong pressure for agricultural land in peri-urban areas. Furthermore, it also indicates how likely it is that the land use will evolve in the future. This suggests that the ALC rate in peri-urban areas will continue to increase and remove agricultural use completely, as has happened elsewhere in Java (See Tables 3 and 5) [44].

Previous studies often relate ALC to rapid urbanization and economic development in urban areas [45-49]. A common view is that urbanization means more people living in urban areas, increasing the demand for land for housing. As agricultural land is flat, it has always been converted to meet this demand. The peri-urban area in our study demonstrates similar conditions. As the Jember economy continues to grow and transform into an industrial and service-based industry, it promotes rapid urbanization. This rapid urbanization affects agricultural regions around the urban core, especially

1 Many house renters in the peri-urban area are college students who rent houses in groups to reduce the average rental per person. Other house renters are typically small families who prefer smaller to larger houses. 
in the form of ALC. ${ }^{2}$ Farmers often converted their land because the incentive received from the agricultural sector is much less enticing than that received from other sectors. Moreover, a high land price for housing motivates farmers to sell it for cash. Farmers receive high compensation from selling land, although they actually face difficulties in managing it for investments [50]. In addition, although rural areas currently record zero ALC, the narrow difference in land economic value indicates that ALC can happen any time in the future, since farmers tend to be willing to sell their land only when it has a high economic value $[27,28,28-30]$.

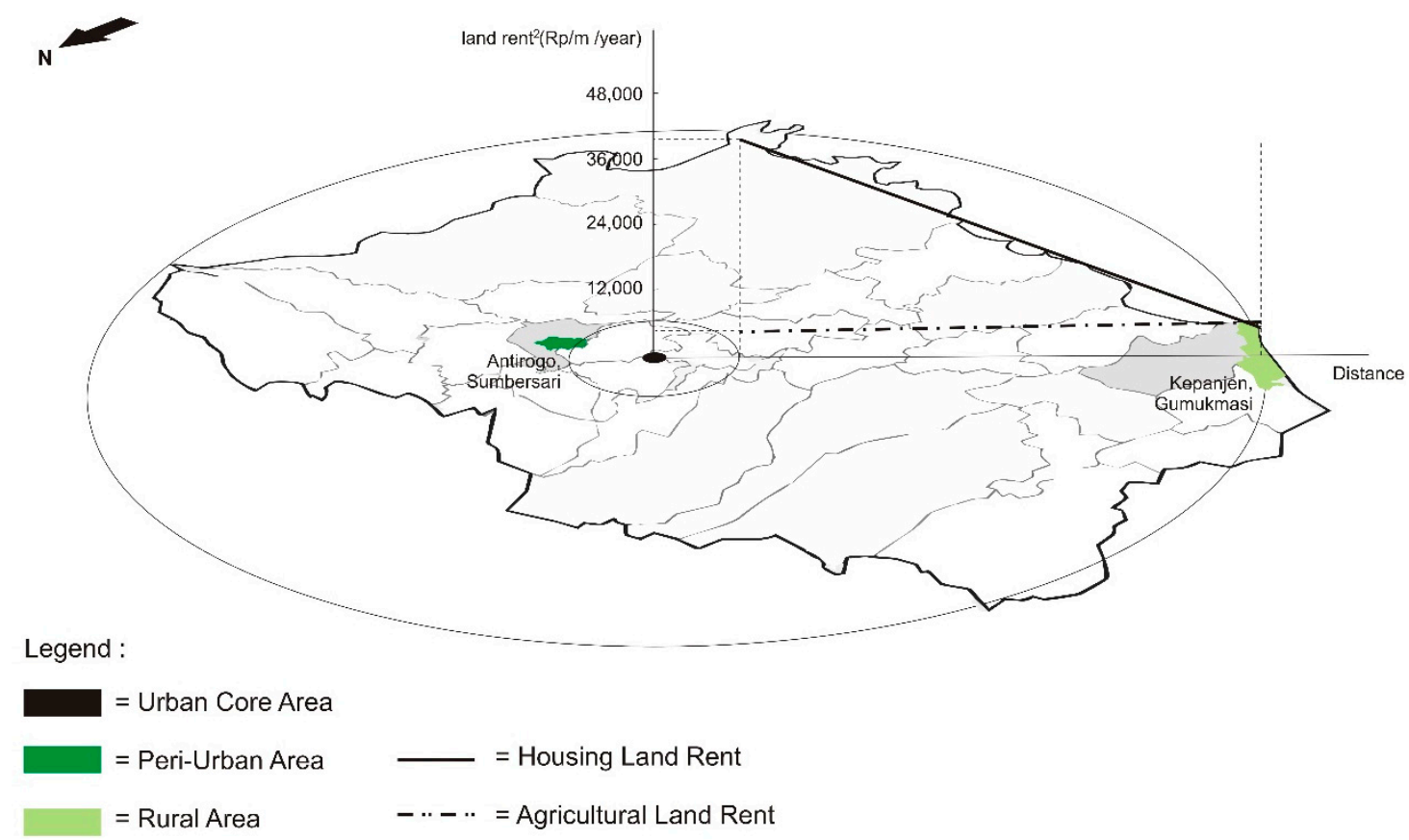

Figure 5. Rent distance diagram of agricultural and housing land use in Jember. Housing land use forms a steeply downward curve from peri-urban to rural areas, while agricultural land use forms a slightly upward curve.

\subsection{Factors Affecting Land Economic Value}

The next result of our study on the factors affecting land economic value supports the findings of previous studies. We found that land area decreases land value, both for agricultural and housing uses. This result is in line with the finding of [51-55] that the economic value decreases with an increase in land area. The intensity of labor and input use declines with increasing farm size; hence, the productivity of the land and hence net return declines. In addition, in rural areas, farmers with more land tend to cultivate low-risk, low-revenue crops, such as rice and maize. Conversely, farmers with a smaller amount of land tend to maximize their income by cultivating high-value crops, such as horticultural crops. For housing, a larger house requires a higher maintenance cost. In addition, the demand for a larger house is not as high as the demand for a smaller house, since the tenants tend to be small families who prefer a lower rental cost to a large-sized house, or students who are more interested in the number of rooms than the overall size of the house.

The accessibility variables (distance to irrigation, the nearest market, and the road) show a negative effect. This result is in line with the results from [54-57]. A great distance to the nearest

2 In this study, we do not systematically assess the impact of urbanization on agricultural activities in the peri-urban area. However, based on our observation, new housing developments degrade the quality of irrigation infrastructures. Moreover, the pollution from urban activities (especially household) lead to decreasing water quality. Furthermore, many farmers reported that it is difficult to find labor for their agricultural activities, due to the change in employment structure. 
market tends to have a negative effect on land value [58-61]. Similarly, the distance to irrigation and the road has a negative impact on land value [62-64]. Specifically, in the study area, irrigation required a greater fee for plots located far from irrigation canals. Similarly, the distance to the road increased the transportation cost associated with farm production and access difficulties.

This study identified three cropping seasons annually, and most farmers were found to apply crop rotation, with only $1 \%$ of farmers who do not apply crop rotation. Crop rotation was found to positively affect land value, which means that land cultivated with various types of crops in one year (horticulture or plantations, see Figure 6) has a higher economic value than that in which only food crops are cultivated. The difference in the types of crops significantly affects the land value, because it is directly related to the output produced, as well as the price of the output $[59,65]$. We found more cropping patterns in rural than in peri-urban areas. Land suitability is the major cause of this difference, and Kepanjen has more crops that are suitable for a variety of cropping. Furthermore, more farmers in Kepanjen tend to maximize their farm income by cultivating high-value crops. A variable closely related to cropping pattern is land fertility. Measured based on farmer knowledge, land fertility has a positive effect on land value, as has been shown by previous studies $[52,59,63,65,66]$. Moreover, agricultural land in rural areas tend to be more fertile than those in peri-urban areas.

A location dummy (in plots either in peri-urban or rural areas) also has positive impact on land value. The previous result indicated that agricultural land in rural areas has a higher value. To find out whether it is true that the location of agricultural land will statistically affect the land value, location was entered as a dummy variable. The results show that, statistically, location significantly influences land value. The negative sign strengthens the result that the agricultural land in rural areas has a higher value. This result is different from the study of [52], which stated that agricultural land close to downtown Buenos Aires and Wales is of a higher value. This is caused by the different characteristics of the land located in peri-urban and rural areas. These characteristics are cultivated plants. Horticultural commodities cultivated in rural areas have a high sale value. Moreover, the land in this area is fertile ( $90 \%$ of the respondents stated that their land was in a fertile region), and this causes a higher income. In contrast, agricultural land in peri-urban areas, according to $24 \%$ of the farmers, is infertile, even though they planted tobacco, and the yield per unit of land is not too high. Moreover, we found that there is a significant difference in food cropping between rural and peri-urban areas. As can be seen from Table 4, rice-maize cropping in rural areas has a rent of $\mathrm{Rp} 4893 / \mathrm{m}^{2}$ /year, while the same cropping pattern in peri-urban areas has only $\operatorname{Rp} 2738 / \mathrm{m}^{2} /$ year. We found that the average yield of rice in peri-urban areas is higher (6150 kilograms/hectare/season) than in rural areas (4965 kilograms/hectare/season). However, the average farming cost in peri-urban areas is significantly higher $(\operatorname{Rp} 9,800,000 /$ ha/season) than in rural areas $(\operatorname{Rp} 5,560,000 /$ ha/season). A high farming cost is associated with the intensive use of hired labor in peri-urban areas. Furthermore, the average output prices received by farmers in rural areas is higher ( $R p 4774 / \mathrm{kg})$, compared to those in peri-urban areas (Rp 4120/kg).

\subsection{Policy Implications}

Finally, although this study was conducted at the village level, the results can be generalized to the conditions of other areas. The similarity of the results with the findings of previous studies from around the world shows that this study can be generalized. There is a strong basis to support the hypothesis that ALC is driven by the significant difference in the land economic value of land with different purposes. We predict that in the future, ALC in peri-urban areas will continue to increase, since the demand for housing is not showing any sign of decreasing. In addition, we stated that, in rural areas, although they are currently experiencing zero ALC, and agricultural production is also playing a central economic role, there is a possibility that ALC will occur in the future. The slight difference in land value in rural areas shows that the resistance towards converting agricultural land to nonagricultural land is weak. 


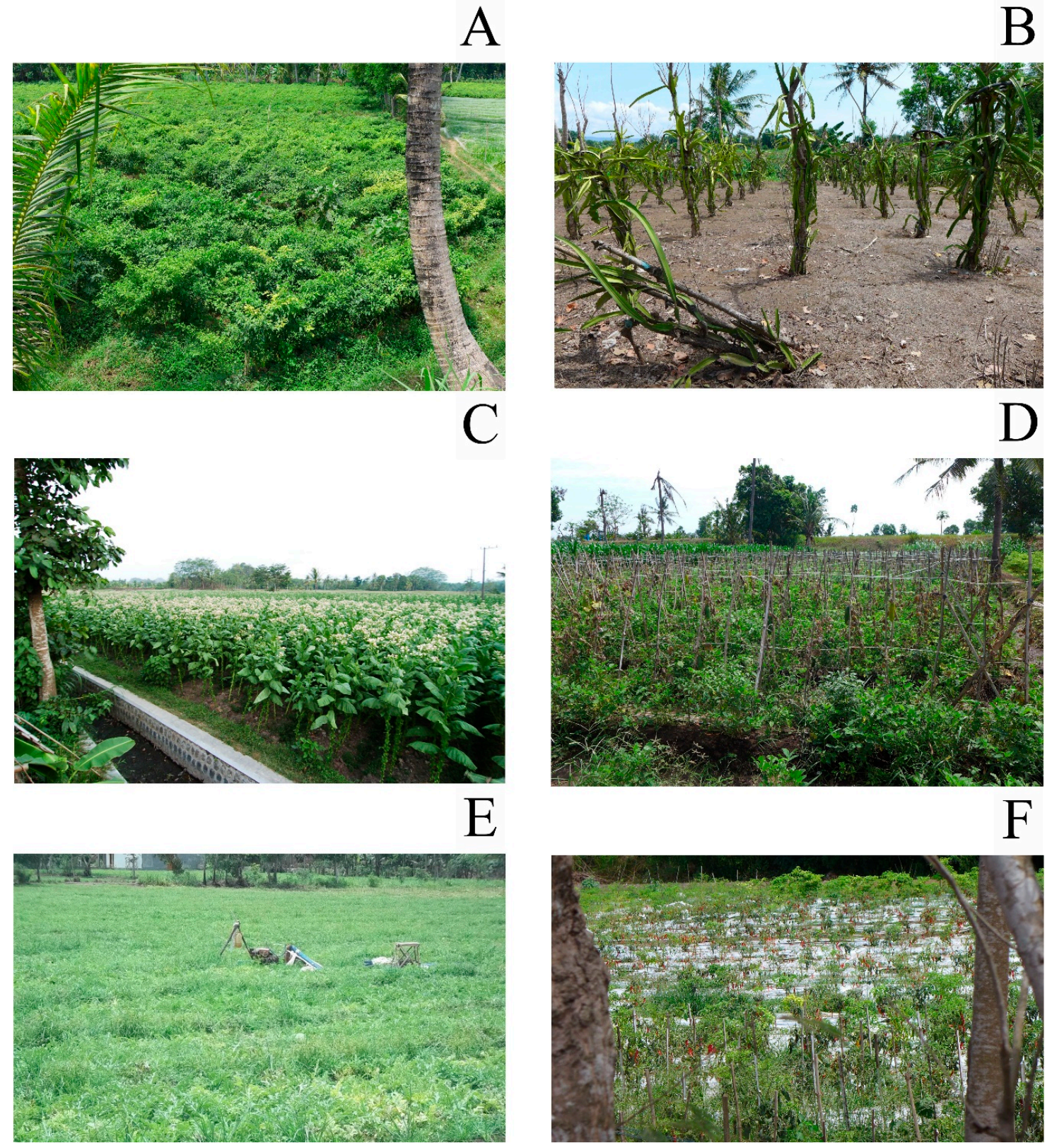

Figure 6. Horticultural and seasonal plantation crops. (A) Cayenne pepper in Kepanjen, (B) Dragon fruit in Kepanjen, (C) Tobacco in Antirogo, (D) Bitter melon in Kepanjen, (E) Water melon in Kepanjen, (F) Chili in Kepanjen

However, there are two exceptions to this. First, in peri-urban areas, the minimum value for agricultural land has a negative sign. This means that there are farmers who choose to preserve their land, even at the expense of profit. As shown by [67], there is a growing number of farmers who choose to remain in farming, and who do not participate in land speculation and the real estate market (peri-urban farmers). The important point of this is that farmers tend to retain their farmland and thus prevent ALC. A systematic identification of these farmers, and a targeted incentive for their farming activity, will surely increase their motivation to continue farming. Second, in rural areas, although the economic value generated by farming is only a little higher than that for housing, farmers have started to cultivate high-value crops. This shows that there is a shift of motive in farming in rural areas, from subsistence to commercial farming. If the number of commercial farmers increases, the possibility of ALC in rural areas will be significantly lower. 
In the context of Indonesian National Policy, the agricultural sector faces a difficult problem in relation to ALC. As a developing country, the Indonesian economic and demographic structure is experiencing rapid transformation into a more industrialized and modern society. Consequently, the need for land, whether for housing or industrial purposes, is high. On the other hand, there is a strong need to preserve agricultural land to support food security. Thus, preventing ALC and preserving agricultural land requires a properly planned policy. Based on the results of this study, we suggest three options that can be used to control ALC in rural and peri-urban areas within the framework of land economic value.

1. The current incentive mechanism, contained in UU No. 41 Tahun 2009, should be focused on farmers in peri-urban areas, specifically those who choose to remain in farming, even at the expense of profit (peri-urban farmer), since the current incentive mechanism requires proactive and highly motivated farmers.

2. There should be an effort to encourage farmers to cultivate crops that are suitable to the land characteristics. Cultivating high-value crops actually increases land value. However, land quality (fertility) will be degraded if the land is forced to produce crops that are basically unsuitable for its characteristics $[68,69]$. This is one of the major causes of land quality degradation. Since land fertility is proven to positively affect land value, both theoretically and empirically, uncontrolled land quality degradation will sacrifice the sustainability of agriculture itself. Thus, it is important to conduct a detailed analysis of land suitability in relation to cropping patterns, especially in rural areas. This should be the main agenda in the framework of increasing the agricultural land economic value in rural areas.

3. The growing number of commercial farmers in rural areas should be supported by granting them access to timely information regarding market conditions and farm technology. Commercial farmers tend to be more responsive to new information and technology. Thus, improving their access to technology will further improve their farming productivity [70,71].

\section{Conclusions}

This study attempted to measure the economic value of land in rural and peri-urban areas, both for agricultural and non-agricultural use. The main thesis of this study is that land value is the main driver of agricultural land conversion. A high value of agricultural land for agricultural use limits land conversion, and vice versa. The result of this study supports the previous thesis. In peri-urban areas, where the demand for housing is high, the land value for housing increases rapidly, thus promoting agricultural land conversion, while in rural areas, where agriculture is the main economic activity, agricultural land has a higher value. We also found that peri-urban farmers, who choose to remain in farming and retain their farmland, even at the expense of profit, have emerged. In rural areas, there is a growing number of commercial farmers who easily rotate their cultivated crop with a high-value one, and although they receive a high economic return, they tend to neglect land suitability and practices chemical-intensive farming, resulting in the potential degradation of land quality.

Below we pointed the important limitations of this study:

- The data used in this study came only from two villages representing peri-urban and rural areas, respectively, and they also had only one period of observation. The information gained will be useful by adding a spatial and temporal dimension to the data. Thus, we leave this endeavor to the future studies.

- The peri-urban land use studied in this study consisted only of housing. Although this is the major form of peri-urban land use in our study area, future studies will produce important results by incorporating other forms of peri-urban land-use.

- We have found a puzzling anomaly between food cropping in rural and peri-urban areas, especially with the output price being different. The information that we collected in this study is not adequate to explain this anomaly. Thus, we leave this endeavor for future research. 
Finally, we propose a further research direction based on the results of this study. This research direction will provide information, in an effort to increase land economic value for agricultural use in order to prevent and control ALC. The required further research directions are:

- Systematically identifying the characteristics of peri-urban farmers and thoroughly exploring what motivates them to remain in farming and retaining their farmland;

- Identifying the characteristics of commercial farmers in rural areas, and tracing how they acquire information regarding market conditions and technology that that they use in making farm decisions; and

- Conducting an agricultural land suitability analysis and measuring the economic benefits of cultivating crops that are suitable for the land characteristics.

Author Contributions: Conceptualization, M.R., P.A.P., V.T.H., A.F.S., and S.A.B.; Data curation, M.R., P.A.P., V.T.H., A.F.S., and S.A.B.; Formal analysis, M.R., P.A.P., V.T.H., A.F.S., and S.A.B.; Funding acquisition, M.R., A.F.S., and S.A.B.; Methodology, M.R., P.A.P., V.T.H., and S.A.B.; Project administration, M.R., A.F.S., and S.A.B.; Supervision, M.R.; Visualization, S.A.B.; Writing—original draft, M.R., P.A.P., V.T.H., A.F.S., and S.A.B.

Funding: This research was funded by the Regional Development Planning Agency (BAPPEDA), Jember, grant number: 074/339.1/310/2017.

Acknowledgments: In this section, we wish to acknowledge the helpful cooperation of farmers and home-owners who were interviewed in this study. We also feel thankful to the Regional Government of Jember and the Jember University for supporting this study. Personally, we wish to acknowledge the helpful contribution of Yoga Satria Siaga in the preparation of this manuscript. We are grateful for two anonymous reviewers who provided encouraging and constructive comments, and especially for the Academic Editor, Rob Cramb, who provide thorough revisions and insightful comments, suggestions, and improvements, which significantly improved the initial version of the manuscript. Finally, all errors are ours.

Conflicts of Interest: The authors declare no conflict of interest.

\section{References}

1. Sitko, N.J.; Jayne, T.S. Structural transformation or elite land capture? The growth of "emergent" farmers in Zambia. Food Policy 2014, 48, 194-202. [CrossRef]

2. Muyanga, M.; Jayne, T.S.; Burke, W.J. Pathways into and out of Poverty: A Study of Rural Household Wealth Dynamics in Kenya. J. Dev. Stud. 2013, 49, 37-41. [CrossRef]

3. $\mathrm{Li}, \mathrm{J}$. Land sale venue and economic growth path: Evidence from China 's urban land market. Habitat Int. 2014, 41, 307-313. [CrossRef]

4. Azadi, H.; Ho, P.; Hasfiati, L. Agricultural land conversion drivers: A comparison between less developed, developing and developed countries. Land Degrad. Dev. 2011, 22, 596-604. [CrossRef]

5. Deloitte. The Food Value Chain A Challenge for the Next Century; Deloitte: London, UK, 2013.

6. Karunakaran, N. Cropping Pattern and Land Degradation in Kasaragod, Kerala. Rajagiri J. Soc. Dev. 2014, 6, 5-20.

7. Singh, P.; Nair, A. Environmental Sustainability of Cropping Patterns in Gujarat; IRMA Working Paper Series; Institute of Rural Management Anand: Gujarat, India, 2012.

8. Kutywawo, D.; Chemura, A.; Chagwesha, T. Soil Quality and Cropping Patterns as A ffected by iIrigation Water Quality in Mutema Irrigation. In 13th WaterNet /WARFSA/GWP-SA International Symposium on Integrated Water Resource Management (IWRM); Global water Partnership-South Africa: Johannesburg, South Africa, 2012.

9. Schneider, A.; Woodcook, C.E. Compact, Dispersed, Fragmented, Extensive? A Comparison of Urban Growth in Twenty-five Global Cities using Remotely Sensed Data, Pattern Metrics and Census Information. Urban Stud. 2008, 45, 659-692. [CrossRef]

10. Simon, D. Urban Environtments: Issues on the Peri-Urban Fringe. Annu. Rev. Environ. Resour. 2008, 33, 167-185. [CrossRef]

11. Webster, D. On the Edge: Shaping the Future of Peri-urban East Asia; Stanford University/Asia Pasific Research Center: Stanford, CA, USA, 2001.

12. Malaque, I.R.; Yokohari, M. Urbanization process and the changing agricultural landscape pattern in the urban fringe of Metro Manila, Philippines. Environ. Urban. 2007, 19, 191-206. [CrossRef] 
13. Yokohari, M.; Takeuchi, K.; Watanabe, T.; Yokota, S. Beyond greenbelts and zoning - A new planning concept for the environment of Asian mega-cities. Landsc. Urban Plan. 2000, 47, 159-171. [CrossRef]

14. Ives, C.D.; Kendal, D. Values and attitudes of the urban public towards peri-urban agricultural land. Land Use Policy 2013, 34, 80-90. [CrossRef]

15. Tassinari, P.; Torreggiani, D.; Benni, S. Dealing with agriculture, environment and landscape in spatial planning: A discussion about the Italian case study. Land Use Policy 2013, 30, 739-747. [CrossRef]

16. Zasada, I. Multifunctional peri-urban agriculture-A review of societal demands and the provision of goods and services by farming. Land Use Policy 2011, 28, 639-648. [CrossRef]

17. Zezza, A.; Tasciotti, L. Urban agriculture, poverty, and food security: Empirical evidence from a sample of developing countries. Food Policy 2010, 35, 265-273. [CrossRef]

18. Bryld, E. Potentials, problems, and policy implications for urban agriculture in developing countries. Agric. Hum. Values 2003. [CrossRef]

19. McGee, T.G. Building Liveable Cities in Asia in the Twenty-First Century Research and Policy Challenges for the Urban Future of Asia. Malays. J. Environ. Manag. 2010, 11, 14-28.

20. Allen, A. Environmental planning and management of the peri-urban interface: Perspectives on an emerging field. Environ. Urban. 2003, 15, 135-148. [CrossRef]

21. Douglass, M. A regional network strategy for reciprocal rural-urban linkages: an agenda for policy research with reference to Indonesia. Third World Plan. Rev. 1998, 20, 1. [CrossRef]

22. North, D.C. Location Theory and Regional Economic Growth. J. Polit. Econ. 1955, 63, 243-258. [CrossRef]

23. Irwin, E.G.; Bockstael, N.E. Interacting agents, spatial externalities and the evolution of residential land use patterns. J. Econ. Geogr. 2002, 2, 31-54. [CrossRef]

24. Irwin, E.G.; Bockstael, N.E. The evolution of urban sprawl: Evidence of spatial heterogeneity and increasing land fragmentation. Proc. Natl. Acad. Sci. USA 2007, 104, 33-46. [CrossRef] [PubMed]

25. Imhoff, M.L.; Lawrence, W.T.; Stutzer, D.C.; Elvidge, C.D. A technique for using composite DMSP/OLS “city lights" satellite data to map urban area. Remote Sens. Environ. 1997, 61, 361-370. [CrossRef]

26. Foley, J.A.; DeFries, R.; Asner, G.P.; Barford, C.; Bonan, G.; Carpenter, S.R.; Chapin, F.S.; Coe, M.T.; Daily, G.C.; Gibbs, H.K.; et al. Global Consequences of Land Use. Science 2005, 309, 570-574. [CrossRef] [PubMed]

27. Kilian, S.; Antón, J.; Salhofer, K.; Röder, N. Impacts of 2003 CAP reform on land rental prices and capitalzation. Land Use Policy 2012, 29, 789-797. [CrossRef]

28. Latruffe, L.; Le Mouël, C. Capitalization of government support in agricultural land prices: What do we know? J. Econ. Surv. 2009, 23, 659-691. [CrossRef]

29. Feichtinger, P.; Salhofer, K. What do we know about the influence of agricultural support on agricultural land prices. In German Journal of Agricultural Economics; Swinnen, J., Knops, L., Eds.; Centre For European Policy Studies (CEPS): Brussels, Belgium, 2013; Volume 62, pp. 71-85.

30. Ciaian, P.; Kancs, D.; Swinnen, J. The Impact of Decoupled Payments on Land Prices in the EU. In Land, Labour and Capital Markets in European Agriculture: Diversity Under a Common Policy; Swinnen, J., Knops, L., Eds.; Centre For European Policy Studies (CEPS): Brussels, Belgium, 2013; pp. 28-42.

31. Milczarek-Andrzejewska, D.; Zawalińska, K.; Czarnecki, A. Land-use conflicts and the Common Agricultural Policy: Evidence from Poland. Land Use Policy 2018, 73, 423-433. [CrossRef]

32. Alam, M.J. Rapid urbanization and changing land values in mega cities: implications for housing development projects in Dhaka, Bangladesh. Bandung J. Glob. South 2018, 5, 2. [CrossRef]

33. Pribadi, D.O.; Pauleit, S. The dynamics of peri-urban agriculture during rapid urbanization of Jabodetabek Metropolitan Area. Land Use Policy 2015, 48, 13-24. [CrossRef]

34. Firman, T.; Dharmapatni, I.A.I. The challenges to sustainable development in Jakarta metropolitan region. Habitat Int. 1994, 18, 79-94. [CrossRef]

35. Firman, T. From 'global city' to 'city of crisis': Jakarta metropolitan region under economic turmoil. Habitat Int. 1999, 23, 447-466. [CrossRef]

36. Firman, T. Rural to urban land conversion in Indonesia during boom and bust periods. Land Use Policy 2000, 17, 13-20. [CrossRef]

37. Firman, T. The continuity and change in mega-urbanization in Indonesia: A survey of Jakarta-Bandung Region (JBR) development. Habitat Int. 2009, 33, 327-339. [CrossRef]

38. Hudalah, D.; Firman, T. Beyond property: Industrial estates and post-suburban transformation in Jakarta Metropolitan Region. Cities 2012, 29, 40-48. [CrossRef] 
39. Agus, F. Irawan Agricultural Land Conversion As A Threat to Food Security and Environtmental Quality. J. Litbang Pertan. 2006, 25, 90-98.

40. Irawan, B. Meningkatkan Efektivitas Kebijakan Konversi Lahan. Forum Penelit. Agro Ekon. 2008, 26, $116-131$. [CrossRef]

41. Government of Indonesia. Perlindungan Lahan Pertanian Berkelanjutan; Indonesian Ministry of Law and Human Rights: Jakarta, Indonesia, 2009; p. 24.

42. BPS-Statistics of Jember Regency. Jember Regency in Figures; BPS Kabupaten Jember: Jember, Indonesia, 2017.

43. Lima, A.C.R.; Hoogmoed, W.B.; Brussaard, L.; Sacco Dos Anjos, F. Farmers' assessment of soil quality in rice production systems. NJAS Wagening. J. Life Sci. 2011, 58, 31-38. [CrossRef]

44. Manganelli, B.; Murgante, B. The Dynamics of Urban Land Rent in Italian Regional Capital Cities. Land 2017, 6, 54. [CrossRef]

45. Peerzado, M.B.; Magsi, H.; Sheikh, M.J. Land use conflicts and urban sprawl: Conversion of agriculture lands into urbanization in Hyderabad, Pakistan. J. Saudi Soc. Agric. Sci. 2018. [CrossRef]

46. Kontgis, C.; Schneider, A.; Fox, J.; Saksena, S.; Spencer, J.H.; Castrence, M. Monitoring peri-urbanization in the greater Ho Chi Minh City metropolitan area. Appl. Geogr. 2014, 53, 377-388. [CrossRef]

47. Wasilewski, A.; Krukowski, K. Land conversion for suburban housing: A study of urbanization around Warsaw and Olsztyn, Poland. Environ. Manag. 2004, 34, 291-303. [CrossRef] [PubMed]

48. Phuc, N.Q.; Westen, A.C.M.; Zoomers, A. Agricultural land for urban development: The process of land conversion in Central Vietnam. Habitat Int. 2014, 41, 1-7. [CrossRef]

49. Xiao, R.; Liu, Y.; Huang, X.; Shi, R.; Yu, W.; Zhang, T. Exploring the driving forces of farmland loss under rapidurbanization using binary logistic regression and spatial regression: A case study of Shanghai and Hangzhou Bay. Ecol. Indic. 2018, 95, 455-467. [CrossRef]

50. Nguyen, T.H.T.; Tran, V.T.; Bui, Q.T.; Man, Q.H.; de Vries Walter, T. Socio-economic effects of agricultural land conversion for urban development: Case study of Hanoi, Vietnam. Land Use Policy 2016, 54, 583-592. [CrossRef]

51. Brown, K.; Barrows, R. The impact of soil conservation investments on land prices. Am. J. Agric. Econ. 1985, 67, 943-947.

52. Maddison, D. A hedonic analysis of agricultural land prices in England and Wales. Eur. Rev. Agric. Econ. 2000, 27, 519-532. [CrossRef]

53. Maddison, D.J. A spatio-temporal model of farmland values. J. Agric. Econ. 2009, 60, 171-189. [CrossRef]

54. Troncoso, J.L.; Aguirre, M.; Manriquez, P.; Labarra, V.; Ormazábal, Y. Influence of physical attributes on the price of land: the case of the Province of Talca, Chile. Cienc. Investig. Agrar. 2010, 37, 105-112. [CrossRef]

55. Yoo, J.; Simonit, S.; Connors, J.P.; Maliszewski, P.J.; Kinzig, A.P.; Perrings, C. The value of agricultural water rights in agricultural properties in the path of development. Ecol. Econ. 2013, 91, 57-68. [CrossRef]

56. Chicoine, D.L. Farmland Values at the Urban Fringe: An Analysis of Sale Prices. Land Econ. 1981, 57, $353-362$. [CrossRef]

57. Sklenicka, P.; Molnarova, K.; Pixova, K.C.; Salek, M.E. Factors affecting farmland prices in the Czech Republic. Land Use Policy 2013, 30, 130-136. [CrossRef]

58. Kellerman, A. Rent from Agricultural Land Around Metropolitan Areas. Geogr. Anal. 1978, 10, 1-12. [CrossRef]

59. Choumert, J.; Phélinas, P. A Hedonic Analysis of Agricultural Land Values in a Gm Soybean Area of Argentina. In Proceedings of the EAAE 2014 Congress 'Agri-Food and Rural Innovations for Healthier Societies', Ljubljana, Slovenia, 26-29 August 2014; pp. 1-14.

60. Banski, J. Changes in agricultural land ownership in Poland in the period of the market economy. Agric. Econ. 2011, 57, 93-101.

61. Dirgasová, K.; Bandlerová, A.; Lazíková, J. Factors affecting the price of agricultural land in Slovakia. J. Cent. Eur. Agric. 2017, 18, 291-304. [CrossRef]

62. Joshi, J.; Ali, M.; Berrens, R.P. Valuing farm access to irrigation in Nepal: A hedonic pricing model. Agric. Water Manag. 2017, 181, 35-46. [CrossRef]

63. Nivens, H.D.; Kastens, T.L.; Dhuyvetter, K.C.; Featherstone, A.M.; Allen, M.; Nivens, H.D.; Kastens, T.L.; Dhuyvetter, K.C.; Featherstone, A.M. Using Satellite Imagery in Predicting Kansas Farmland Values Linked references are available on JSTOR for this article: Using Satellite Imagery in Predicting Kansas Farmland Values. J. Agric. Resour. Econ. 2002, 27, 464-480. 
64. Nickerson, C.; Morehart, M.; Kuethe, T.; Beckman, J.; Ifft, J.; Williams, R. Trends in U.S. Farmland Values and Ownership. USDA Econ. Inf. Bull. 2012, 92, 48.

65. Choumert, J.; Phélinas, P. Determinants of agricultural land values in Argentina. Ecol. Econ. 2015, 110, $134-140$. [CrossRef]

66. Kocur-bera, K. Determinants of agricultural land price in Poland-A case study covering a part of the Euroregion Baltic. Cah. Agric. 2016. [CrossRef]

67. Yagi, H.; Garrod, G. The future of agriculture in the shrinking suburbs: The impact of real estate income and housing costs. Land Use Policy 2018, 76, 812-822. [CrossRef]

68. Vasu, D.; Srivastava, R.; Patil, N.G.; Tiwary, P.; Chandran, P.; Kumar Singh, S. A comparative assessment of land suitability evaluation methods for agricultural land use planning at village level. Land Use Policy 2018, 79, 146-163. [CrossRef]

69. Akinci, H.; Özalp, A.Y.; Turgut, B. Agricultural land use suitability analysis using GIS and AHP technique. Comput. Electron. Agric. 2013, 97, 71-82. [CrossRef]

70. Zhou, J.; Cheng, C.; Kang, L.; Sun, R. Integration and Analysis of Agricultural Market Information Based on Web Mining. IFAC-PapersOnLine 2018, 51, 778-783. [CrossRef]

71. Ziolkowska, J.R. Economic value of environmental and weather information for agricultural decisions-A case study for Oklahoma Mesonet. Agric. Ecosyst. Environ. 2018, 265, 503-512. [CrossRef]

(C) 2018 by the authors. Licensee MDPI, Basel, Switzerland. This article is an open access article distributed under the terms and conditions of the Creative Commons Attribution (CC BY) license (http:/ / creativecommons.org/licenses/by/4.0/). 